\title{
HIV Prevention in Brazil
}

\section{K. Bell (Kristen Bell)}

University of Scranton of Panuska College of Professional Studies,

Original Articles

Office of Undergraduate Admissions, 800 Linden Street, Scranton, PA 18510-4699

\section{E-mail address:}

kristen.bell@scranton.edu

\section{Reprint address:}

University of Scranton of Panuska College of Professional Studies

Office of Undergraduate Admissions

800 Linden Street

Scranton, PA 18510-4699

Suource: Clinical Social Work and Health Intervention

Volume: 7

Issue: 4

Pages: $33-40$

Cited references: 8

\section{Reviewers:}

Dr. Michael Costello, MA, MBA, J.D.

University of scranton school of education, USA

e-mail: michael.costello@scranton.edu

Dr.S.R. Boselin Prabhu, DUC., B.E., M.E., Ph.D

V.S.B College of Engineering-Technical Campus, Coimbatore, India

e-mail: eben4uever@gmail.com

\section{Key words:}

HIV, Prevention, Brazil, Antiretroviral treatment.

\section{Publisher:}

International Society of Applied Preventive Medicine i-gap

CSWHI 2016; 7(4): 33 - 40; DOI 10.22359/cswhi_7_4_05 @ 2016 Clinical Social Work and Health Intervention

\section{Abstract:}

HIV is a significant health concern worldwide, and combating this disease is an important millennium development goal formulated at the United Nations Millennium Summit in 2000. A target was set to halt HIV/AIDS by 2015 and reverse its spread (Skolnik 2016). Brazil sets a high standard of protocol for the prevention and treatment of HIV and AIDS, not only in Latin America, but on a global level. The prevalence of HIV in Brazil, Latin America, and worldwide are examined, along with HIV prevention and treatment strategies in Brazil. Studies that have been 
conducted in other Latin American countries are reviewed that imply the critical role education and community organizations have in combating the disease which focus on key populations and high-risk groups. The impact of the prevention and treatment strategies in Brazil demonstrate the strong political and ethical commitment Brazil has towards the health of their population.is very rare, CRP response in a patient was significant.

\section{Introduction}

Human Immunodeficiency Virus (HIV) continues to be a growing pandemic concern. HIV is spread through certain body fluids that attack the body's immune system, specifically the CD4 or T cells. The human body cannot rid itself of HIV. Once HIV is acquired, it is present for life. HIV destroys many $\mathrm{T}$ cells over time, which hinders the body from fighting off various diseases and infections. HIV can lead to Acquired Immunodeficiency Syndrome (AIDS) if left untreated. Antiretroviral treatment has been available since the mid-1990s, and it is known to reduce the spread of infection and decrease the risk of the acquirement of AIDS. No cure exists for $\mathrm{HIV}$, so it is critical for individuals at risk or living with HIV to seek education and treatment (CDC 2015).

\section{Prevalence of HIV}

There are an estimated 35 million people worldwide that have been infected with HIV in 2013, and 1.5 million have suffered AIDS-related deaths (Skolnik 2016). There have been 2.1 million people newly affected with HIV in 2013. Of the 35 million people infected with HIV, 55\% are females (Skolnik 2016).

The region with the highest prevalence rate of HIV/AIDS in adults 15-49 years of age is sub-Saharan Africa at $4.7 \%$, followed by Eastern Europe and Central Asia at $0.7 \%$. Brazil and the United States of America have comparable rates of HIV/AIDS, around $0.6 \%$ (Skolnik 2016).

In Latin America, 1.6 million people were living with HIV in 2013, with a prevalence rate of $0.4 \%$. There were 94,000 new infections, 47,000 AIDS-related deaths, and $44 \%$ of adults were on antiretroviral treatment (AVERT 2015).

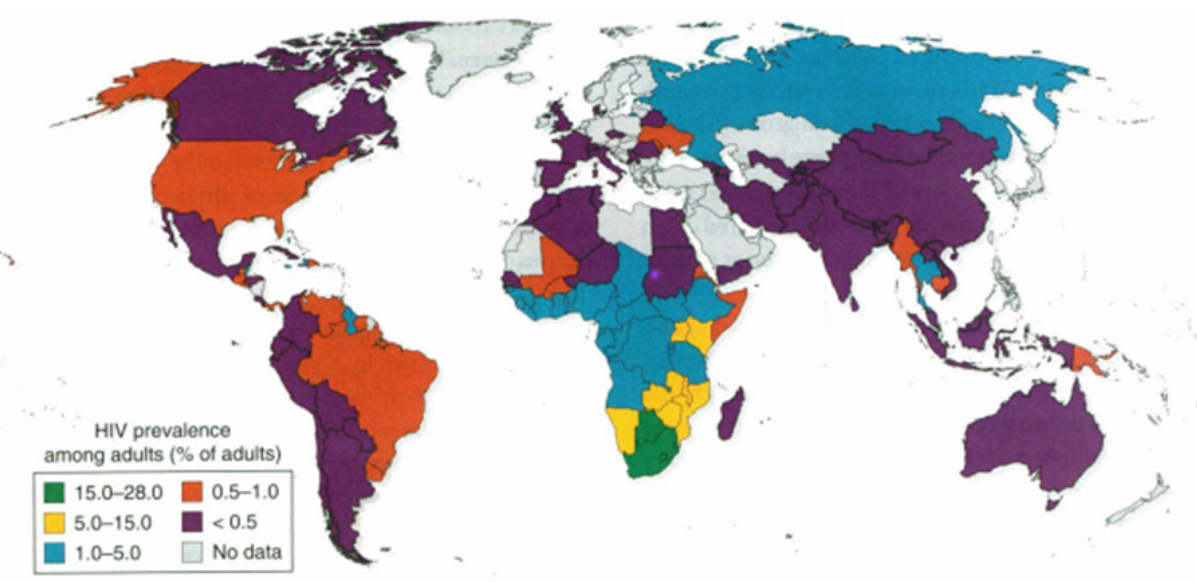

Figure 1 HIV prevalence by country. Reprinted from Global Health $1013^{\text {rd }}$ Ed. (p 327), by R.L. Skolnik 2016, Burlington, MA: Jones and Bartlett Learning. Copyright 2016 by Jones \& Bartlett Learning, LLC, an Ascend Learning Company. 
Brazil represents the largest number of people living with HIV in Latin America at $47.3 \%$. In 2013, there were 730,000 people living with HIV (a prevalence rate of $0.6 \%$ ). In 2013, there have been 44,000 new HIV infections, 16,000 AIDS-related deaths, and $41 \%$ of adults receiving antiretroviral treatment (AVERT 2015). Brazil has seen an average of new infections of HIV on an average of 37,000 between the years 2002 and 2012. There has also been a rise of new infections from 2005 and 2013 by 11\% (AVERT 2015).

\section{High Risk Activities and Key Affected Populations}

HIV can be spread through unprotected sex, mother-to-child transmission during birth or breastfeeding, blood, including by transfusion and needle sharing, and/or transplantation of infected tissue or organs (Skolnik 2016). Uncircumcised males bare a higher risk of acquiring HIV, and females are at a greater biological and social risk than males of being infected with HIV (Skolnik 2016). Male-to-female sexual transmission of HIV is greater than female-to-male transmission (Skolnik 2016). The Progress Report of the Brazilian Response to HIV/AIDS (20102011) examined the high-risk groups of HIV based on studies conducted in 10 Brazilian municipalities between 2008 and 2009 (Manaus, Recife, Salvador, Belo Horizonte, Rio de Janeiro, Santos, Curitiba, Itajaí, Campo Grande and Brasília) (Brazilian Ministry of Health 2012). The estimated prevalence rates of HIV were $10.5 \%$ among men who have sex with men, 5.1\% among sex workers, and 5.9\% among injecting drug users (Brazilian Ministry of Health 2012). It is important to note that sex work is legal in Brazil, which puts these individuals, especially females, at a greater risk of acquiring HIV.

\section{Goals of Brazilian Government}

The government of Brazil has made a significant contribution to the UNAIDS Global AIDS Response Report 2015 which provides progress and challenges of the response to HIV developed by the Department of STI, AIDS and Viral Hepatitis in 2014 (UNAIDS 2015). The government of Brazil and other countries of the Latin American region have set $90 / 90 / 90$ targets to be achieved by the year 2020. These targets are defined as $90 \%$ of people living with HIV/AIDS knowing their HIV status; 90\% of people living with HIV/AIDS receiving antiretroviral treatment; $90 \%$ of people receiving antiretroviral treatment virally suppressed by the year 2020 (UNAIDS 2015). The targets were defined in May 2014 during the first Latin American and Caribbean Forum on the HIV Care Continuum held in Mexico City. The ways in which these goals will be achieved are by increasing access to prevention, diagnosis, and treatment; combating the stigma and discrimination of an HIV diagnosis; promoting the human rights of people living with HIV.

\section{Hiv Continuum of Care in Brazil}

The Global AIDS Response Progress Reporting (GARPR) provides baseline statistics of the HIV Continuum of Care in Brazil adapted from the Ministry of Health/ Surveillance Secretariat/

Department of STI, AIDS, and Viral Hepatitis in 2013. As mentioned previous$1 y$, there were 730,000 people living with HIV and AIDS in Brazil in 2013. Of those $730,000,80 \%(589,000)$ knew their diagnosis. Approximately two thirds of the $80 \%$ $(537,000)$ had been linked to health services, and $61 \%(448,000)$ were retained in care. Of the $48 \%(355,000)$ receiving antiretroviral treatment, $82.5 \%(293,000)$ of those receiving antiretroviral treatment had an undetectable virus load (UNAIDS, 2015). 


\section{HIV Prevention Strategies in Brazil}

In 2013, the Department of STI, AIDS, and Viral Hepatitis, in partnership with the Ministry of Health and civil society organizations in Brazil, launched "Viva Melhor Sabendo" or "Live Better Knowing" as a strategy for rapid HIV testing with oral fluid among the key populations. The name of the project refers to the benefits of knowing an HIV diagnosis. Testing occurs in the communities of Brazil that have participating organizations. In the first stage of the project, 36 cities in all five regions of Brazil were involved. "Viva Melhor Sabendo" uses a peer sharing strategy which is defined as the "sharing of knowledge between equals or between people or groups having the same profile and sharing the same experiences thus facilitating the exchange of knowledge and practices" (UNAIDS 2015). This strategy enables key populations to be reached in key locations outside of healthcare facilities and the spread of information of HIV to peers of similar backgrounds. At the end of 2014, "Viva Melhor Sabendo" was carried out in partnership with 48 non-governmental organizations (NGOs) from four key populations connected to HIV: gay men, transgenders, sex workers, and people who use drugs (UNAIDS 2015). Tests performed by this project are displayed in Table 1. Of the number of people tested between March 2014 and January 2015, $43 \%$ were never tested before the project, and $29 \%$ of the positive cases were never tested before the project (UNAIDS 2015).

The prevention of HIV from mother to child transmission is attempted by the provision of routine recommendations that HIV positive mothers do not breastfeed; rapid HIV testing in maternity units; routine recommendations that all pregnant women should be tested (AVERT 2015). Over the last 10 years, the detection rates of HIV among pregnant women have increased significantly: in 2004 the rate was 2.0 cases per 1,000 live births, which increased to 2.5 cases in 2013. The AIDS detection in newborns has significantly decreased since 2004 by $35.7 \%$ (UNAIDS 2015).

Table 1 Tests by "Viva Melhor Sabendo"March 2014- Jan 2015

\begin{tabular}{|lrcc|}
\hline Key Populations & $\begin{array}{c}\text { \# of People } \\
\text { Tested }\end{array}$ & $\begin{array}{c}\text { \# of Positive } \\
\text { Cases }\end{array}$ & $\begin{array}{c}\text { \% of Positive } \\
\text { Cases }\end{array}$ \\
\hline Transvestites & 626 & 80 & $12.8 \%$ \\
Transsexuals & 435 & 29 & $6.6 \%$ \\
Male sex workers & 504 & 21 & $4.1 \%$ \\
Female sex workers & 3,418 & 40 & $1.2 \%$ \\
People who use drugs & 2,697 & 47 & $1.7 \%$ \\
Gay men \& other & 3,011 & 142 & $4.7 \%$ \\
MSM & & & \\
Other populations & 5,142 & 52 & $1.0 \%$ \\
Total & 15,833 & 411 & $2.6 \%$ \\
\hline
\end{tabular}

Table 1 Tests performed by "Viva Melhor Sabendo" March 2014 - January 2015. Adapted from "The Brazilian Response to HIV and AIDS." (2015) Global AIDS Response Progress Reporting Narrative Report, UNAIDS. Brasilia, DF. 
The government of Brazil has guaranteed universal and free of charge access to antiretroviral treatment for people living with HIV and AIDS since 1996. In 2002, there were 300,000 people worldwide receiving HIV treatment, and half of those people were receiving treatment in Brazil (WHO 2013). This suggests the impact of the strong political commitment Brazil has towards fighting HIV and the mobilization of substantial resources throughout Brazil. By 2011, 80\% of people living with HIV and AIDS were receiving antiretroviral treatment, and the mortality rates of AIDS-related deaths significantly decreased (WHO 2013). Mortality rates of AIDS-related deaths compared to non-AIDS-related and unknown deaths are shown in Figure 2. positive adults begin treatment regardless of their CD4 cell count, or before their immune system has yet been compromised. "Option B+" was implemented in 2012, which allows pregnant women to begin treatment regardless of their CD4 cell count. "Test and Treat" was implemented in 2013, which expanded this philosophy to all HIV positive adults. Brazil was the third country in the world to adopt the "Test and Treat" program in its nation recommendations (UNAIDS 2015). These programs are used as forms of prevention of the spread of the disease.

In 2014, 75,000 new people living with HIV and AIDS were receiving treatment, which was a $31 \%$ increase since 2013 . Based on the clinical data, $36 \%$ of Brazilians receiv-

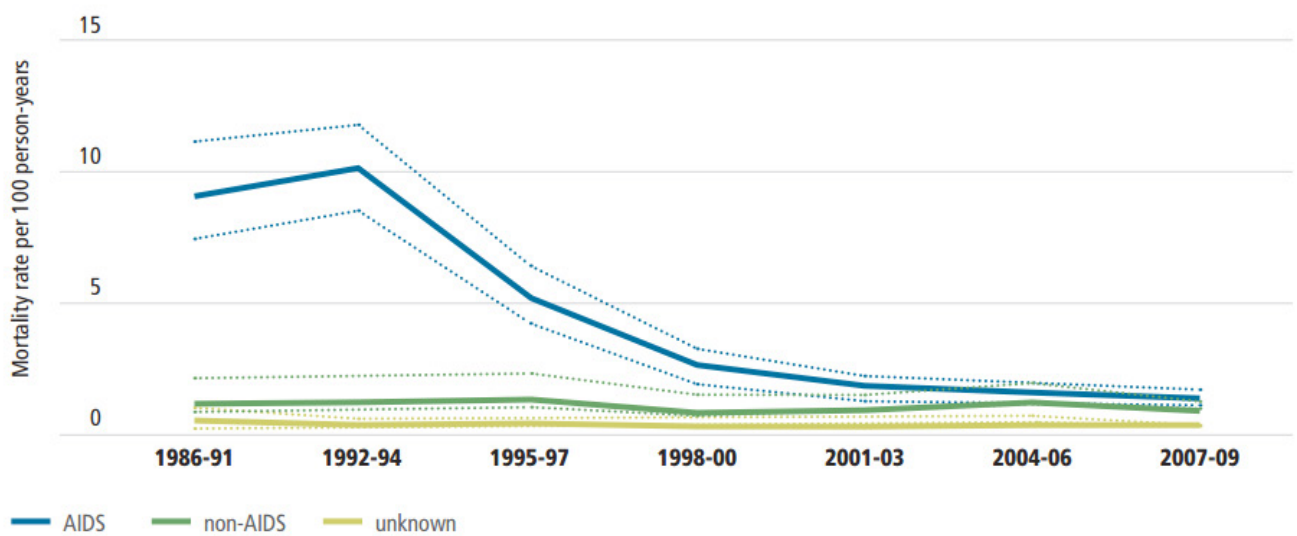

Figure 2 Mortality Rates in Brazil for AIDS-related, non-AIDS-related, and unknown causes of death, 1986-2009. Reprinted from Global Update on HIV Treatment 2013: Results, Impact and Opportunities (p. 44) 2013 World Health Organization.

In Brazil, the mortality rates from AIDS-related causes have declined dramatically, from 9.2 deaths per 100 person-years in 1986-1991 to 1.4 deaths per 100 person - years in 2007-2009. The rates of non-AIDS-related deaths and unknown causes of death have remained relatively stable over time (WHO 2013).

There are treatment programs in Brazil that have been implemented to allow HIV ing treatment in 2014 had CD4 cell counts above 500 cells $/ \mathrm{mm}^{3}$. This data suggests the prevention strategy is effective (UNAIDS 2015). Overall, there is a tendency of towards a decrease in the population of people living with HIV and AIDS seeking health services with late HIV infection (CD4 counts below 200 cells $/ \mathrm{mm}^{3}$ ), decreasing from $31 \%$ in 2009 to $26 \%$ in 2014 (UNAIDS 2015). 


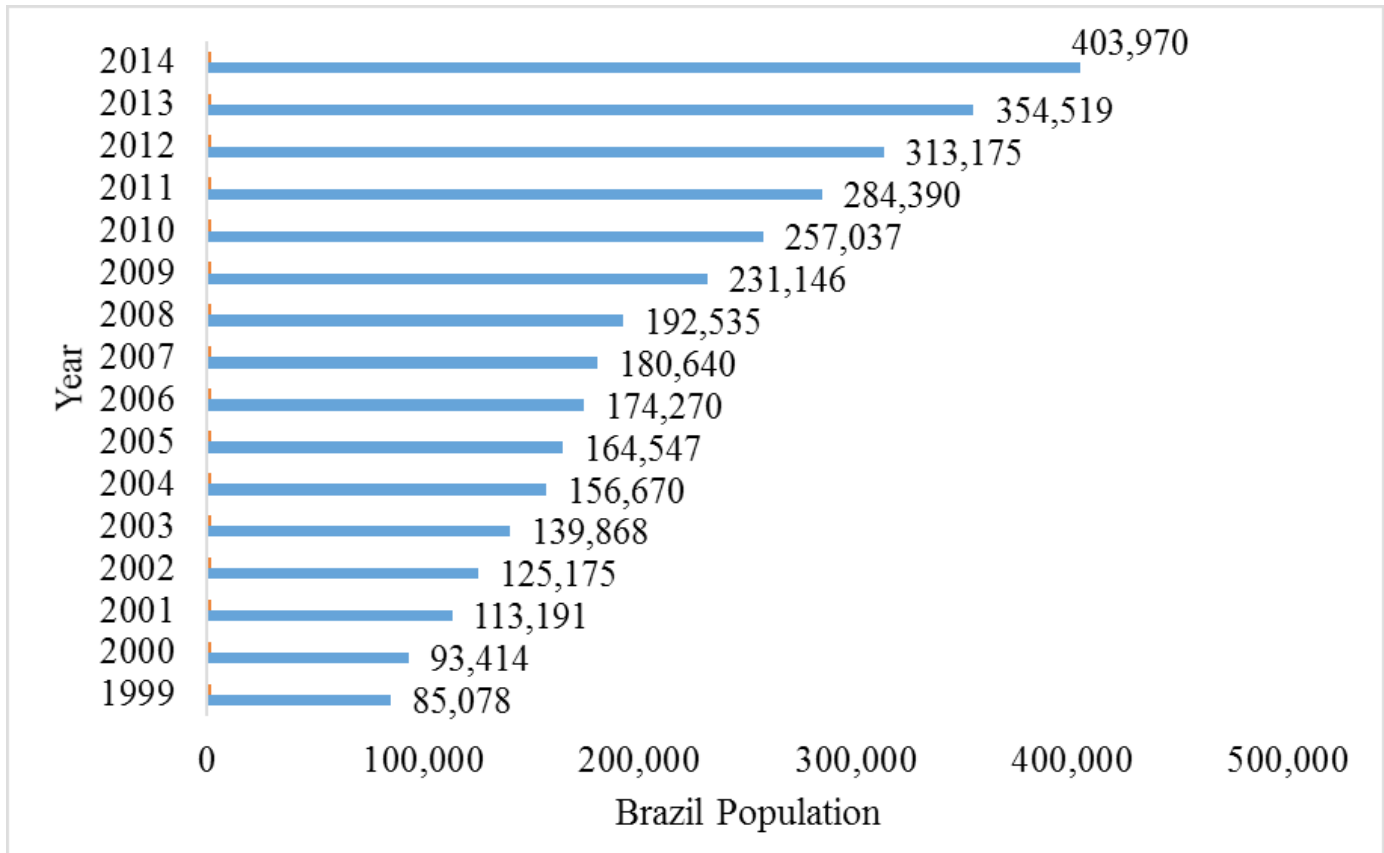

Figure 3 Evolution of ART. Reprinted from The Brazilian Response to HIV and AIDS (p. 50) in Global AIDS Response Progress Reporting, 2015, Brasilia: UNAIDS.

\section{Hiv Prevention Studies in Other Latin American Countries}

HIV testing and counseling to low income and key populations is vital to reduce the spread and increase the education of HIV. Community leaders play a critical role in education, which is evident from an HIV testing and counseling study conducted in Colombia by the Corporación de Lucha Contra el Sida (CLS) published in AIDS Research and Treatment (2014). This study noted that a mere $20 \%$ of individuals in Colombia are tested for HIV (Galindo-Quintero et al 2014). CLS implemented a multidisciplinary, provider-initiated, population-based HIV testing and counseling strategy called BAFI. CLS used two different approaches: the 1st Group was led by healthcare providers (BAFI-1); the 2nd was led by CLS and community leaders (BAFI-2). Both groups provided consented HIV screening testing; a demographic questionnaire; self-reported HIV knowledge and behavior questionnaires; pre \& posttest counselling; confirmatory HIV tests; clinical follow-up; access to comprehensive care; antiretroviral treatment (Galindo-Quintero et al 2014). The results for this study for BAFI-1 and BAFI-2 are respectively: HIV positive-confirmed prevalence $=0.29 \% \& 3.86 \%$; return rate for confirmatory results $=62.5 \% \&$ $93.7 \%$; return rate for comprehensive care $=83.3 \% \& 92.8 \%$, and ART initiation rate $=20 \% \& 76.9 \%$ (Jaime Galindo-Quintero et al 2014). BAFI-2 was significantly more effective on each indicator used in the approaches. This study implies that community-based approaches to high-risk groups are optimal, and it supports the community-based education strategy used in Brazil, "Viva Melhor Sabendo."

The impact of a professionally-facilitated peer group was examined in a study conducted in Chile, known as "Mano a Mano: Mujer" published in Health Care Women 
International (2012). The intervention and control groups consisted of low-income Latino women between 20 and 40 years of age. The peer group consisted of trained female health educators that provided the intervention group with six sessions, two hours each, of education on various HIV topics. directed to the key populations at risk, as well as treatment programs that are shown to be effective. As mentioned previously, the goal established by the Brazilian government is to reach $90 / 90 / 90$ targets by 2020. Based on the baseline statistics of the HIV continuum of care in Brazil, it is possible to achieve these targets. Brazil has set an

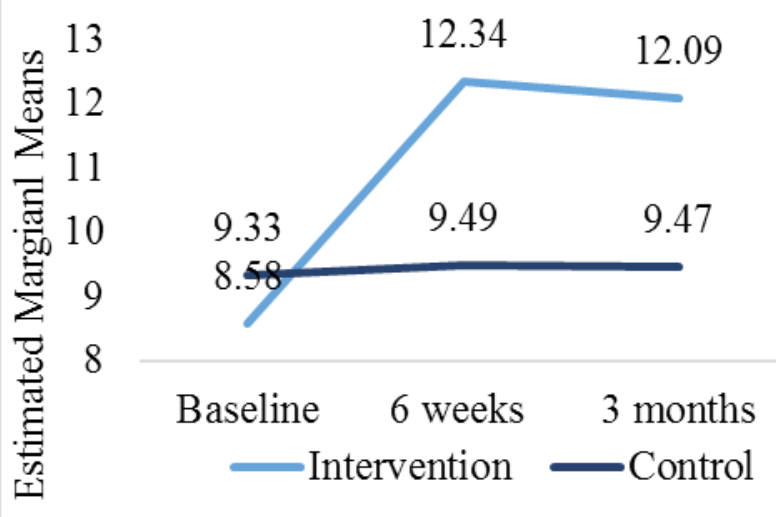

Figure 4 HIV risk knowledge at baseline, six weeks, and three months of follow up. Reprinted from "Mano a Mano Mujer: An Effective HIV Prevention for Chilean Women," by Cianelli, R. et al 2012, Health Care Women International, 33(4). 2012 by PubMed Central.

The results displayed in Figure 4 show the intervention group had significantly higher rates of HIV-related knowledge, more positive attitudes towards people living with HIV, greater self-efficacy, more communication with their partners of safe sex, and decreased depression symptoms. This study implies that working with low-income women is a key element for HIV prevention in Chile and Latin America, and should be addressed broadly at a community level.

\section{Conclusion}

HIV is a growing pandemic issue, especially in Africa, Eastern Europe, and Asia. Although Brazil has the highest prevalence rate of $\mathrm{HIV}$ in Latin America, there are strong educational programs implemented example for HIV prevention and treatment for many countries around the world. The studies conducted in Colombia and Chile support the critical roles of the community leaders and organizations for involvement in education and intervention of low-income and key populations at risk, which have been ongoing and supported by the government in Brazil.

\section{References}

1. "About HIV/AIDS." (2015) Centers for Disease Control and Prevention. http:// www.cdc.gov/hiv/basics/whatishiv.html

2. Cianelli, R. et al (2012) Mano a Mano Mujer: An Effective HIV Prevention for Chilean Women. Health Care Women International 33(4): 321-341. Retrieved from 
http://www.ncbi.nlm.nih.gov/pmc/articles/ PMC3348920/

3. Galindo-Quintero, J et al (2014) HIV Testing and Counselling in Colombia: Local Experience on Two Different Recruitment Strategies to Better Reach Low Socioeconomic Status Communities. AIDS Research and Treatment 2014. Retrieved from http:// dx.doi.org/10.1155/2014/803685

4. Čeledová, L., Čevela, R., Vaňásková , E., Bienertová, J., Pražmová, V. 2015: Dopady sociální reformy na posuzování stupně závislosti pro účely pŕispěvku na péči a význam ergodiagnostiky při sociální rehabilitaci jeho pŕ́jemců . In: Rehabilitácia ISSN 0375-0922, Vol. 52, 2015, No 1, p. 38-48

5. Global Update on HIV Treatment 2013: Results, Impact, and Opportunities (2013). World Health Organization. Retrieved from http://www.unaids.org/sites/default/files/ media_asset/20130630_treatment_report_ en_0.pdf
6. HIV and AIDS in Brazil (2015) Averting HIV and AIDS. Retrieved from http://www. avert.org/professionals/hiv-around-world/ latin-america/brazil

7. Progress Report on the Brazilian Response to HIV/AIDS (2010-2011) (2012). Brazilian Ministry of Health, Health Surveillance Secretariat, Department of STD, AIDS, and Viral Hepatitis. Retrieved from http://www. unaids.org/sites/default/files/en/dataanalysis/knowyourresponse/countryprogressreports/2012countries/UNGASS_2012_ingles_rev_08jun.pdf

8. Skolnik, R (2016). Global Health $1013^{\text {rd }}$ ed. Burlington, MA: Jones \& Bartlett Learning.

9. The Brazilian Response to HIV and AIDS. (2015). Global AIDS Response Progress Reporting (GARPR). Retrieved from http:// www.unaids.org/sites/default/files/country/ documents/BRA_narrative_report_2015. pdf 